\title{
Risk of suicide among nursing students
}

\author{
Risco de suicídio entre estudantes de enfermagem \\ Riesgo de suicidio entre estudiantes de enfermería
}

Stephane Marcele Almeida Braga Moraes' ORCID: 0000-0002-7018-6790

Valquíria Farias Bezerra Barbosa' ORCID: 0000-0002-8200-2274

Ana Carla Silva Alexandre' ORCID: 0000-0002-5754-1778

Silvana Cavalcanti dos Santos ORCID: 0000-0002-6649-0423

Fernanda Jorge Guimarães" ORCID: 0000-0003-4618-3730

Juliana Lourenço de Araújo Veras" ORCID: 0000-0003-3833-8421

'Instituto Federal de Educação, Ciência e Tecnologia de Pernambuco. Pesqueira, Pernambuco, Brazil. "Universidade Federal de Pernambuco. Vitória de Santo Antão,

Pernambuco, Brazil.

How to cite this article: Moraes SMAB, Barbosa VFB, Alexandre ACS, Santos SC, Guimarães FJ, Veras JLA. Risk of suicide among nursing students. Rev Bras Enferm. 2021;74(6):e20200867. https://doi.org/10.1590/0034-7167-2020-0867

\section{Corresponding author:}

Stephane Marcele Almeida Braga Moraes E-mail: stephanemarcele@hotmail.com

EDITOR IN CHIEF: Antonio José de Almeida Filho ASSOCIATE EDITOR: Hugo Fernandes

Submission: 09-29-2020

Approval: 11-24-2020

\section{ABSTRACT}

Objectives: to identify the risk and degree of risk of suicide in nursing students of a public institution in the countryside of Pernambuco, Brazil. Methods: this was a cross-sectional, quantitative research conducted with 150 students. For data collection, a sociodemographic questionnaire and the instrument, M.I.N.I. - Brazilian version 5.0.0 - Module C - Risk of suicide were used. Statistical analyses were performed with IBM ${ }^{\circ}$ SPSS, version 23 . Results: $53.3 \%$ of nursing students had a risk of suicide, of which $20.7 \%$ had a high risk. Moreover, $22.67 \%$ reported previous suicide attempt. It is noteworthy that students without a partner have a higher risk of suicide $(56.8 \%)$ than those with a partner $(29.4 \%)$. Conclusions: it is perceived the need to develop programs that identify students at risk of suicide in higher education institutions, in order to raise awareness of the problem and implement policies to promote mental health in the academia. Descriptors:Risk; Suicide; Universities; Students; Nursing.

\section{RESUMO}

Objetivos: identificar o risco e o grau de risco de suicídio em estudantes de enfermagem de uma instituição pública do interior de Pernambuco, Brasil. Métodos: tratou-se de uma pesquisa transversal, quantitativa, realizada com 150 estudantes. Para a coleta de dados utilizou-seum questionário sociodemográfico e o instrumento, M.I.N.I. - versão brasileira 5.0.0-Módulo C - Risco de Suicídio. As análises estatísticasforam realizadas no IBM $^{\circledR}$ SPSS $^{\oplus}$ versão 23. Resultados: $53,3 \%$ dos estudantes de enfermagem apresentaram risco de suicídio; desses, 20,7\% tinham alto risco. Ademais, 22,67\% relataram tentativa de suicídio anterior. Destaca-se que os estudantes sem companheiro apresentam maior percentual de risco de suicídio $(56,8 \%)$ do que os com companheiro $(29,4 \%)$. Conclusões: percebe-se a necessidade do desenvolvimento de programas que identifiquem estudantes com risco de suicídio nas instituições de ensino superior, para a conscientização do problema e a implementação de políticas de promoção da saúde mental no meio acadêmico.

Descritores: Risco; Suicídio; Universidades; Estudantes; Enfermagem.

\section{RESUMEN}

Objetivos: identificar el riesgo y el grado de riesgo de suicidio en estudiantes de enfermería de una institución pública del interior de Pernambuco, Brasil. Métodos: una investigación transversal, cuantitativa, realizada con 150 estudiantes. Para la recolección de datos, un cuestionario sociodemográfico y el M.I.N.I. - versión brasileña 5.0.0-Módulo C-Riesgo de suicidio. Los análisis estadísticos se realizaron en IBM ' SPSS', versión 23. Resultados: el 53,3\% de los estudiantes de enfermería tenían riesgo de suicidio; de estos, el 20,7\% estaban en alto riesgo. Además, el 22,67\% informó de un intento de suicidio previo. Es de destacar que los estudiantes sin pareja tienen un mayor porcentaje de riesgo de suicidio $(56,8 \%)$ que los que tienen pareja $(29,4 \%)$. Conclusiones: existe la necesidad de desarrollar programas que identifiquen a los estudiantes en riesgo de suicidio en las instituciones de educación superior para generar conciencia sobre el problema e implementar políticas para promover la salud mental en la academia.

Descriptores:Riesgo; Suicidio; Universidades; Estudiantes; Enfermería. 


\section{INTRODUCTION}

Suicidal behavior is considered a complex phenomenon, which encompasses three concepts: suicidal ideation, characterized by thoughts or ideas about suicide and/or planning of the subject's own death; suicide attempt, referring to an act committed with the effective intention of ending life; consummated suicide, in which the act previously performed culminated in the death of a subject. This has been considered a serious public health concernworldwide ${ }^{(1)}$.

Overall, global suicide rates are decreasing. However, it is estimated that, annually, more than 800,000 people die by suicide worldwide and, for each of these, at least another 20 have attempted suicide. Thus, in 2012 , suicide became the $15^{\text {th }}$ cause of mortality in the world population, where about $80 \%$ of cases occur in low- and middle-income countries such as Brazil(2).

The most current data on suicide indicators on the map of Brazilian violence showed that in between 2002 and 2012 the number of suicides recorded in Brazilian territory increased by $33.6 \%$, which may have been a reflection of the improvement in records with the effect of Ordinance1,876 of August 14, 2006 ${ }^{(3)}$ from the Ministry of Health, which instituted the Brazilian National Guidelines for Suicide Prevention (DiretrizesNacionais para a Prevenção do Suicídio), which contributed to the dissemination of data and information about suicide. However, this rate surpassed the country's population growth rate in the same period, which was $11.1 \%$. However, in the young population (15-29 years) this increase was less significant, 15.3\% between 2002 and 2012; however, it still remains one of the most notorious causes of deaths in this population group ${ }^{(4)}$.

As far as university students are concerned, suicide is pointed out as the second leading cause of death ${ }^{(5)}$. Thus, the transition to young adult age can generate conflicts, both due to academic and family adversities, as they need to face social, psychological, and biological changes, in addition to knowing how to deal with the demands of adult life satisfactorily. Moreover, nursing's academic attributions and burdens often result in an atmosphere of psychological distress and anguish. This can make up a spectrum of factors predisposing to suicide ${ }^{(6-7)}$.

A study conducted with nursing students from the countryside of São Paulo showed that $12.3 \%$ of students had suicidal ideation ${ }^{(8)}$. This evidences that health students, particularly nursing, may suffer from the process of adaptation to higher education, academic and personal commitments, and with expectations regarding insertion in the world of work in the last years of university, which may be susceptible to the emergence of suicidal behavior. Furthermore, nursing as a profession requires individuals'emotional abilities related to the process of caring for people, which can contribute even more to the emergence of feelings such as anguish, depression, disability, and suicidal behavior, especially in individuals who do not have favorable coping skills or strategies ${ }^{(9-10)}$.

It is also important to recognize the internalization of the suicide phenomenon, with greater exposure to situations of vulnerability and deprivation, especially with regard to young people. Living conditions in the countryside often involve situations of poverty, lack of access to public policies and qualified health care, family conflicts and problems related to emotional involvement; these factors contribute to the appearance of personal conflicts, which makes the population more vulnerable to mental distress and, consequently, to suicidal behavior ${ }^{(11-12)}$.

This is said to be necessary to identify risk of suicide in university students from institutions located in the countryside, in order to plan integrated multidisciplinary actions for suicide prevention, concomitantly with family dynamics, to mitigate the associated risk factors. The experience and adaptation to a new environment may not take place successfully, which is likely to trigger the emergence of negative feelings, which reflect on personal life and in the process of teaching student learningand can lead to risk of suicide ${ }^{(13-15)}$.

Therefore, the present study is relevant, since there are few studies that reveal the risk and degree of risk in the academic population, specifically among nursing students from higher education institutions located in the countryside, where there is a low coverage and a fragility in health network organization, consequently, of the specific programs in mental health.

\section{OBJECTIVES}

To identify risk of suicide and the degree of risk of suicide in nursing students, given that, considering the stressors present in the academic environment, it is possible that there is a greater risk for suicide among university students.

\section{METHODS}

\section{Ethical aspects}

The study began after a Research Ethics Committeeapproval, and was conducted in accordance with the ethical principles contained in Resolution 466/2012 $2^{(16)}$ of the Brazilian National Health Council (Conselho Nacional de Saúde), referring to research involving human beings and after signing the Informed Consent Form by all participants.

\section{Study design, period and location}

This was a cross-sectional research with a quantitative approachconducted by STROBE, together with nursing students from a public higher education institution in the state of Pernambuco, Brazil. The convenience sampling technique was used, in which data collection occurred from September to October 2019.

\section{Population and sample; inclusion and exclusion criteria}

The study population was composed of the total number of students $(\mathrm{N}=170)$ regularly enrolled in the nursing course. However, it is necessary to take into account the loss of samples by students who did not want to participate in the research, in addition to the inclusion and exclusion criteria established. Students aged 18 years or older were included in the study. Those who were on sick leave or, for some reason, were absent from the course during the period of data collection were excluded. Therefore, the study obtained a final sample of 150 students. 


\section{Study protocol}

Data collection occurred from two research instruments: a sociodemographic questionnaire, used to characterize the sample, in order to classify students as to course year, sex, age group, marital status, religion, color/race, and family income; and the International Neuropsychiatric Interview (M.I.N.I. - Brazilian version 5.0.0) - Module C - Risk of suicide, an instrument developed by researchers from the Pitié-SalpêtrièreUniversity Hospital in Paris and the University of Florida, validated in Brazil by Amorim ${ }^{(17)}$. The M.I.N.I. corresponds to a short-term interview, 15 to 30 minutes, intended for use in clinical practice and research, which aims at diagnostic classification in a manner compatible with the criteria of the Diagnostic and Statistical Manual of Mental Disorders - $5^{\text {th }}$ edition (DSM-V). In this study, only module C - Risk of suicide - was assessed, where students were identified as "no risk of suicide", i.e., those who did not score in the test and "at risk of suicide", i.e., students with 1 point or more; of these, the degree of current risk of suicide was identified. Students with a score of 1 to 5 points are considered as "low risk of suicide", 6 to 9 points as "moderate risk of suicide", and 10 points or more, as "high risk of suicide"(17).

Students identified with risk of suicide were made available referral for psychological and psychiatric assistance, since the institution had these services.

The instruments were applied at the educational institution, according to students' available time, by prior appointment and explanation of the data collection procedure. Data collection was performed in a reserved place, with the purpose of ensuring privacy, and for students to have complete freedom to express themselves.

\section{Analysis of results, and statistics}

The results were recorded in an EXCEL spreadsheet, doublechecked. Statistical analyses were conducted through the program Statistical Package for the Social Sciences (IBM ${ }^{\circ}$ SPSS ${ }^{\circ}$ ), version 23.

Data were analyzed descriptively by means of absolute and percentage distributions and were analyzed inferentially by Pearson's chi-square test. To assess the strength of the association, Odds Ratio (OR) was obtained, and confidence intervals for this measure were obtained in the study of the association between variables in the bivariate study.

In order to verify which variables influence the percentage of students who had a risk of suicide, a logistic regression model was adjusted with variables that showed a significant association up to $20 \%(p<0.20)$ in the bivariate study. Variables with $p$ $<0.20$ of the step-back selection process were maintained in the model. From the model, "OR" values, significance values ( $p$ values) of the variables and each category in relation to the reference category were estimated, adjustment of data to the model by the Lemeshow test and percentage of correct classification of cases.

The margin of error used in statistical tests' decisions was $5 \%$, and intervals were obtained with $95 \%$ confidence.

\section{RESULTS}

Regarding the general characteristics of the sample, shown in Table 1, it was noted that students up to the $2^{\text {nd }}$ year of the course were the majority among the research participants (45.4\%), compared to the final two years of the course (33.3\%).

Additionally, there is a predominance of female students (74\%), the age group between 18 and 24 years old (85.3\%), a higher frequency of single students (88\%), Catholics (62.7\%), who are self-declaredmixed-ethnicity (47.3\%), with family income per capita of $1-2$ minimum wages (53.3\%). It is noteworthy that in Brazil, in 2019, the value of the minimum wage was around R\$ 998.00 (about 199 US dollars).

Table 1 - General characteristics of nursing students from a public institution, Pernambuco, Brazil, 2019, $(n=150)$

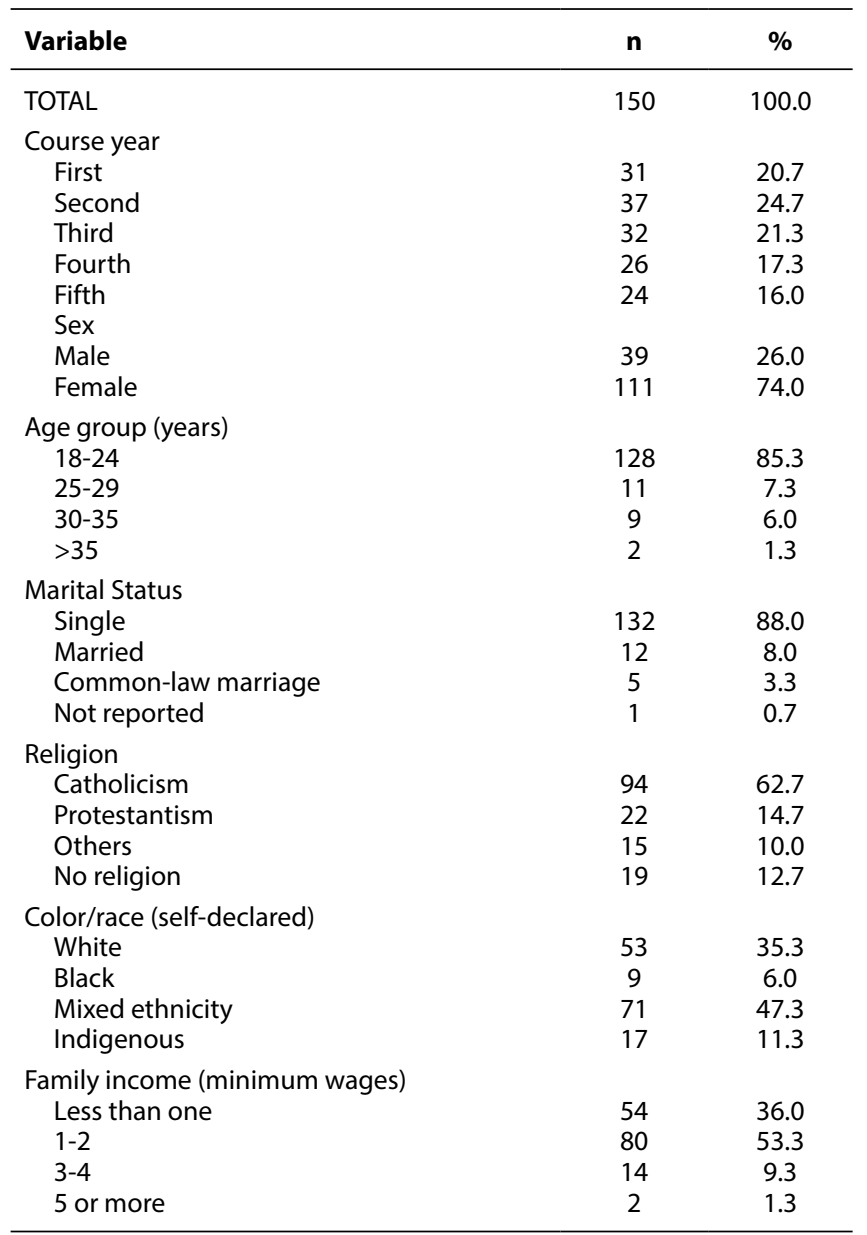

Table 2 -Risk of suicide, degree of risk and suicide attempts of nursing students of a public institution, Pernambuco, 2019, $(n=150)$

\begin{tabular}{lcc}
\hline Variable & $\mathbf{n}$ & $\%$ \\
\hline TOTAL & 150 & 100.0 \\
Risk of suicide & & \\
$\quad$ Yes & 80 & 53.3 \\
$\quad$ No & 70 & 46.7 \\
Degree of risk of suicide & & \\
$\quad$ No risk & 70 & 46.7 \\
$\quad$ Low & 31 & 20.7 \\
$\quad$ Moderate & 18 & 12.0 \\
$\quad$ High & 31 & 20.7 \\
Previous suicide attempts & & \\
$\quad$ Yes & 34 & 22.7 \\
$\quad$ No & 116 & 77.3 \\
\hline
\end{tabular}


Concerning risk of suicide, the data in Table 2 show that $53.3 \%$ of nursing students were at risk of suicide; of these, $20.7 \%$ were at high risk, and $20.7 \%$, at low risk of suicide. Concomitantly, 34 students (22.7\%) reported a history of previous suicide attempt.

Table 3 shows the results of the study of the association between the risk of suicide and the general data of the sample. To calculate the associations, the variables were concatenated to find the significant values. For the fixed margin of error (5\%), marital status was the only variable with a significant association with the risk of suicide ( $p<0.05$ and OR intervals that exclude the value 1.00), and for that variable, it is highlighted that the percentage of students at risk of suicide was higher among those without a partner (56.8\%) than those with a partner (29.4\%).

With regard to Table 4, of the variables analyzed in the bivariate study, three had $p<0.20$ and were included in the initial model.
Variables included were course year, marital status, religion, and religion was excluded from these. Of the variables maintained in the model for $p<0.20$, only marital status was significant at $5 \%$; for that variable, OR value shows that there is a likelihood that a nursing student from the researched population will be at risk of suicide if they do not have a partner.

Other results of the model showed that the data were well adjusted according to the Lemeshow test $(p=0.842)$ and correctly classified the cases in $64.4 \%$ of the ones surveyed.

\section{DISCUSSION}

In the present study, a high risk of suicide rate was evidenced among nursing students (53.3\%), in which $20.7 \%$ of students had a high risk, and $20.7 \%$ had a low risk of suicide.

Table 3 -Risk of suicide according to independent variables of nursing students from a public institution, Pernambuco, Brazil, 2019, (n=150)

\begin{tabular}{|c|c|c|c|c|c|c|c|c|}
\hline \multirow{3}{*}{ Variable } & \multicolumn{4}{|c|}{ Risk of suicide } & \multirow{2}{*}{\multicolumn{2}{|c|}{ Total }} & \multirow{3}{*}{ OR (95\%) } & \multirow{3}{*}{$p$ value } \\
\hline & \multicolumn{2}{|c|}{ Present } & \multicolumn{2}{|c|}{ Absent } & & & & \\
\hline & $\mathbf{n}$ & $\%$ & $\mathbf{n}$ & $\%$ & $\mathbf{n}$ & $\%$ & & \\
\hline Total group & 80 & 53.3 & 70 & 46.7 & 150 & 100.0 & & \\
\hline Course year & & & & & & & & $\mathrm{p}^{(1)}=0.141$ \\
\hline First & 17 & 54.8 & 14 & 45.2 & 31 & 100.0 & $1.70(0.58$ a 4.98$)$ & \\
\hline Second & 26 & 70.3 & 11 & 29.7 & 37 & 100.0 & 3.31 (1.13 a 9.69) & \\
\hline Third & 14 & 43.8 & 18 & 56.3 & 32 & 100.0 & $1.09(0.37$ a 3.18$)$ & \\
\hline Fourth & 13 & 50.0 & 13 & 50.0 & 26 & 100.0 & $1.40(0.46$ a 4.28$)$ & \\
\hline Fifth & 10 & 41.7 & 14 & 58.3 & 24 & 100.0 & 1.00 & \\
\hline Sex & & & & & & & & $\mathrm{p}^{(1)}=0.654$ \\
\hline Male & 22 & 56.4 & 17 & 43.6 & 39 & 100.0 & $1.18(0.57$ a 2.47$)$ & \\
\hline Female & 58 & 52.3 & 53 & 47.7 & 111 & 100.0 & 1.00 & \\
\hline Age group (years) & & & & & & & & $p^{(1)}=0.902$ \\
\hline $18-24$ & 68 & 53.1 & 60 & 46.9 & 128 & 100.0 & 1.00 & \\
\hline 25 or more & 12 & 54.5 & 10 & 45.5 & 22 & 100.0 & $1.06(0.43$ a 2.63$)$ & \\
\hline Marital status & & & & & & & & $\mathrm{p}^{(1)}=0.033^{*}$ \\
\hline Without a partner & 75 & 56.8 & 57 & 43.2 & 132 & 100.0 & 3.16 (1.05 a 9.47) & \\
\hline With a partner & 5 & 29.4 & 12 & 70.6 & 17 & 100.0 & 1.00 & \\
\hline Total & 80 & 53.7 & 69 & 46.3 & 149 & 100.0 & & \\
\hline Religion & & & & & & & & $p^{(1)}=0.158$ \\
\hline With religion & 67 & 51.1 & 64 & 48.9 & 131 & 100.0 & 1.00 & \\
\hline No religion & 13 & 68.4 & 6 & 31.6 & 19 & 100.0 & 2.07 (0.74 a 5.77) & \\
\hline Color & & & & & & & & $\mathrm{p}^{(1)}=0.317$ \\
\hline White & 27 & 50.9 & 26 & 49.1 & 53 & 100.0 & 1.00 & \\
\hline Black/mixed ethnicity & 41 & 51.3 & 39 & 48.8 & 80 & 100.0 & $1.01(0.51$ a 2.03$)$ & \\
\hline Indigenous & 12 & 70.6 & 5 & 29.4 & 17 & 100.0 & $2.31(0.71$ a 7.48$)$ & \\
\hline $\begin{array}{l}\text { Family income } \\
\text { (minimum wages) }\end{array}$ & & & & & & & & $\mathrm{p}^{(1)}=0.946$ \\
\hline Less than one & 29 & 53.7 & 25 & 46.3 & 54 & 100.0 & $1.02(0.52$ a 1.99$)$ & \\
\hline One or more & 51 & 53.1 & 45 & 46.9 & 96 & 100.0 & 1.00 & \\
\hline
\end{tabular}

(*) Significant association at 5\%; (1) By Pearson's chi-square test.

Table 4 - Results of logistic regression for the prevalence of risk of suicide of nursing students from a public institution, Pernambuco, Brazil, 2019, ( $=150$ )

\begin{tabular}{|c|c|c|c|c|}
\hline \multirow{2}{*}{ Variable } & \multicolumn{2}{|c|}{ Bivariate } & \multicolumn{2}{|c|}{ Adjusted } \\
\hline & OR and $95 \%$ IC & $p$ value & OR and $95 \%$ IC & $p$ value \\
\hline Course year & & 0.141 & & 0.158 \\
\hline First & 1.70 (0.58 a 4.98$)$ & & $0.93(0.25$ a 3.43$)$ & \\
\hline Second & 3.31 (1.13 a 9.69) & & $2.77(0.88$ a 8.64$)$ & \\
\hline Third & $1.09(0.37$ a 3.18$)$ & & 0.85 (0.27 a 2.67) & \\
\hline Fourth & $1.40(0.46$ a 4.28$)$ & & 1.57 (0.49 a 5.08$)$ & \\
\hline Fifth & 1.00 & & 1.00 & \\
\hline Marital status & & $0.033^{*}$ & & $0.044^{*}$ \\
\hline Without a partner & 3.16 (1.05 a 9.47) & & $3.46(1.05$ a 11.36$)$ & \\
\hline With a partner & 1.00 & & 1.00 & \\
\hline
\end{tabular}


These results were superior to other studies conducted with the university population in the health field. In Brazil, a study conducted with 142 students from the state of Piauí identified $22 \%$ of university students with suicidal ideation ${ }^{(13)}$. Another study conducted with 271 students from a public institution in Pernambuco found that $13.6 \%$ had a risk of suicide ${ }^{(18)}$. Researches carried out in other countries with nursing students also showed lower rates than those found in this study. In the province of Barcelona, a study found that $6.4 \%$ of students had risk of suicide ${ }^{(19)}$. In Coimbra, Portugal, a study found that $5.2 \%$ of students had previous suicidal behavior ${ }^{(20)}$. It is worth mentioning that the variation of results may be related to the different instruments used for the studies.

Furthermore, in this study, $22.7 \%$ of students had a history of previous suicide attempt. Another study carried out with 1,567 nursing students, from a private institution in the Federal District, found that $11.5 \%$ had previously attempted suicide ${ }^{(9)}$.It is known that the previous suicide attempt is the main predisposing factor for suicide ${ }^{(21)}$, especially if students express negative feelings or thoughts, since many already arrive at the University with suicidal behavior $^{(13)}$. Thus, strategies for the prevention, identification, monitoring and support of university students at risk of suicide, associated with families and the psychosocial care network, are necessary to strengthen bonds and welcoming listening to these students ${ }^{(9)}$.

It should also be consideredthe several risk factors for suicide, which act individually as genetic, cultural, sociodemographic, and personal factors ${ }^{(21-22)}$; in particular, during the transition from adolescence to adulthood to a large portion of academics, in which it is often necessary to move away from family members and affective bonds ${ }^{(6)}$. It is noteworthy that the impacts generated depend on individual resilience to manage the events of life, in addition to the support network of each student ${ }^{(23)}$.

Additionally, the risk of suicide among university students may occur due to the high level of academic stress, exhaustive workload, and insecurity in relation to professional future. In fact, it is expected that nursing students develop skills to deal with the process of illness and care in nursing. This can generate a higher risk of suicide for those who still cannot cope with the duality and ephemerality of life $\mathrm{f}^{(19)}$.

Moreover, it is known that health professionals have a higher risk of suicide than the general population, since they work alongside human suffering, and are responsible for assisting those who demand their care. Precarious working conditions and low professional recognition can cause personal conflicts and increased risk of suicide ${ }^{(22,24-25)}$. Therefore, it is necessary to invest in professional training and valorization, in order to provide better working conditions, since nurses play an important role in prevention and care related to suicidal behavior ${ }^{(26)}$.

Regarding the associations between risk of suicide and independent variables, it was found that the risk of suicide was higher among nursing students without a partner. This corroborates the results of a study carried out in Portugal with university students, in which suicidal ideation was greater in single and divorced people than in married ones ${ }^{(27)}$. Furthermore, it is observed that suicide rates among people without a partner are higher than those of people with a partner, given that the presence of children can be a protective factor, especially for women ${ }^{(22,28)}$. Thus, Durkheim's theory of marital status for suicide was confirmed, in which having a partner or being married and having a family is a factor in the protection and promotion of mental health, which reduces suicidal behavior ${ }^{(29)}$ as a social support network is created that in stressful situations can bring practical help and emotional comfort ${ }^{(22)}$.

In contrast, $46.7 \%$ of students were not at risk for suicide. This may occur due to the existence of good relationships and bonds of social support, self-confidence, willingness to seek help, in addition to resilient capacity, good health habits and quality of life, which are protective factors and result in a better adaptation of the young person higher education and greater satisfaction with the course and life $\mathrm{e}^{(20,22)}$.

It is worth mentioning that the percentage differences found in the studies may occur due to the different types of instruments used, the sociodemographic characteristics of each region and country, in addition to the sample size. This reinforces the need for detailed studies on the theme that include other courses and/ or institutions to analyze the singularities of the health determinants of each context, the effects of academic aspects and their association with suicidal behavior. Thus, it becomes possible to more accurately identify the risk of suicide and establish conducts to improve the academic environment as a whole.

\section{Study limitations}

It was verified that the research was restricted to a single educational institution and a single course, which configured a small sample.Moreover, although there are several scales and strategies to identify risk of suicide in a population, unfortunately none of them demonstrated full efficiency for detectingrisk of suicide ${ }^{(30)}$, since the results can be influenced by ephemeral feelings. Moreover, despite the psychometric adequacy to the MINI interview, the results may have been influenced by the brevity of the responses, in addition to respondents'embarrassment, who may have omitted or modified some information despite the proper environment for conducting the interview and confidentiality.

However, given the high prevalence of suicidal ideation among university students ${ }^{(5-8)}$, it is of great importance that a summary assessment of suicide ideas be carried out in an attempt to develop suicide prevention actions for this group.

\section{Contributions to nursing, health, and education}

From the results, it is possible to give greater visibility to the situation in higher education institutions by mapping the courses. Furthermore, the study encouraged the implementation of institutional programs to promote suicide prevention and improve the mental health of students and future professionals. Nursing professionals also need resilience to deal with different situations in their daily lives. Thus, nurses must have skills that assist the multidisciplinary team in coping with suicide, acting in care identification, planning, implementation, and assessment. It is suggested that professionals and institutions be trained to manage the suicidal behavior of professionals in training.

\section{CONCLUSIONS}

It was observed that $53.3 \%$ of the nursing students of the institution surveyed presented risk of suicide, of which $20.7 \%$ 
were identified with high risk. The study also confirmed that having a partner is a factor in protecting and promoting mental health, which reduces risk of suicide.

Such findings signal the need to develop programs that identify students at risk of suicide in higher education institutions to raise awareness of the problem and implement policies to promote mental health in the academic environment, with information, prevention and intervention actions. This study raises a reflection of managers and professors of educational institutions for a more collaborative performance, with greater institutional support and jointly with the support network of students with suicidal behavior.

\section{REFERENCES}

1. Gonçalves AM, Sequeira CAC, Duarte JC, Freitas PP. Suicidal ideation on higher education students: influence of some psychosocial variables. Arch Psychiatr Nurs. 2016;30(2):162-6. https://doi.org/10.1016/j.apnu.2015.08.005

2. World Health Organization (WHO). Preventing suicide. CMAJ [Internet]. 2014 [cited 2020 Jun 08];143(7):609-10. Available from: https://apps. who.int/iris/bitstream/handle/10665/131056/9789241564779_eng.pdf;jsessionid=A785219BCD9CA5E1FA55BBA8C851A162?sequence=1

3. Ministério da Saúde (BR). Portaria n 1.876 de 14 de agosto de 2006. Diretrizes brasileiras para um plano nacional de prevenção do suicídio. Brasília: MS; 2006.

4. Waiselfisz JJ. Os jovens do Brasil: mapa da violência. Brasília, DF: Seppir; 2014.170 p.

5. Santos HGB, Marcon SR, Espinosa MM, Baptista MN, Paulo PMC. Factors associated with suicidal ideation among university students. Rev Latino-Am. Enfermagem. 2017;25:e2878. https://doi.org/10.1590/1518-8345.1592.2878

6. Vêncio APS, Sousa NG, Paulo KCM, Mathias EF, Aguilar RR. The beginning of university life versus suicidal desire. Braz J Of Develop. 2019;5(11):25019-33. https://doi.org/10.34117/bjdv5n11-176

7. Vasconcelos-Raposo J, Soares AR, Silva F, Fernandes MG, Teixeira CM. Levels of suicidal ideation among young adults. Estud Psicol (Campinas). 2016;33(2):345-54. https://doi.org/10.1590/1982-02752016000200016

8. Botti NCL, Monteiro AMC, Benjamin ALN, Queiroz LC. Depressão, uso de drogas, ideação e tentativa de suicídio entre estudantes de enfermagem. Revista de Enfermagem UFPE. 2016;10(7):2611-6. https://doi.org/10.5205/reuol.9106-80230-1- SM1007201639

9. Albuquerque RN, Borges MS, Monteiro PS. Epidemiological profile of suicidal behavior among nursing students. Rev Enferm UERJ. 2019;27:e45607. https://doi.org/10.12957/reuerj.2019.45607

10. Santa ND, Cantilino A. A review of literature on suicide among doctors and medical students. Rev Bras Educ Med. 2016;40(4):772-80. https:// doi.org/10.1590/1981-52712015v40n4e00262015

11. Aaron R, Joseph A, Abraham S, Muliyil J, George K, Prasad J, et al. Suicides in young people in rural Southern India. Lancet. 2004;363:1117-8. https://doi.org/10.1016/S0140-6736(04)15896-0

12. Dimenstein MDB, Leite JF, Macedo JPS, Dantas CMB. Condições de vida e saúde mental em contextos rurais. São Paulo, SP: Intermeios. 2016;16(1):151-8. https://doi.org/10.20396/sss.v16i1.8651478

13. Veloso LUP, Lima CLS, Sales JCS, Monteiro CFS, Gonçalves AMS, Silva Jr FJG. Suicidal ideation among health field undergraduates: prevalence e associated factors. Rev Gaúcha Enferm. 2019;40:e20180144. https://doi.org/10.1590/1983-1447.2019.20180144

14. Penso MA, Sena DPA. Young people's hopelessness and suicide as a solution. Soc Estado. 2020;35(1):61-81. https://doi.org/10.1590/ s0102-6992-202035010004

15. Moreira LCO, Bastos PRHO. Prevalence and risk factors associated with suicidal ideation in adolescents: literature review. Psicol Esc Educ. 2015;19(3):445-53. https://doi.org/10.1590/2175-3539/2015/0193857

16. Conselho Nacional de Saúde (BR). Resolução CNS n 466, de 12 de dezembro de 2012. Aprova diretrizes e normas regulamentadoras de pesquisas envolvendo seres humanos. Diário Oficial da União. Brasília: MS. 2013.

17. Amorim P. Mini International Neuropsychiatric Interview (MINI): validação de entrevista breve para diagnóstico de transtornos mentais. Rev Bras Psiquiatr. 2000;22(3):106-15. https://doi.org/10.1590/S1516-44462000000300003

18. Nascimento VS, Santos AV, Arruda SB, Silva GA, Cintra JDS, Pinto TCC, et al. Association between eating disorders, suicide and depressive symptoms in undergraduate students of health-related courses. Einstein (São Paulo). 2020;18:eAO4908. https://doi.org/ 10.31744/ einstein_journal/2020ao4908

19. Montes-Hidalgo J, Tomás-Sábado J. Autoestima, resiliencia, locus de controle y riesgo suicida en estudiantes de enfermeira. Enferm Clín. 2016;26(3):188-93. https://doi.org/10.1016/j.enfcli.2016.03.002

20. Leal SC, Santos JC. Suicidal behaviors, social support and reasons for living among nursing students. Nurs Educ Today. 2016;36:434-8. https://doi.org/10.1016/j.nedt.2015.09.012

21. Nascimento IMC, Morales DRD. Suicidal behavior in nursing students of Campus Senator Helvidius Nunes de Barros; Federal University of Piaui. Acad Rev Investig Cienc Soc Human [Internet]. 2016 [cited 2020 Jun 08];3(1). Available from http://revistacientifica.uamericana.edu. py/index.php/academo/article/view/33

22. Botega NJ. Crise suicida: avaliação e manejo. Porto Alegre (RS): Artmed; 2015. 304 p. 
23. Venicio RH, Daiuto PR. O papel da resiliência na prevenção do suicídio. Rev Uningá Rev [Internet]. 2017 [cited 2020 Jun 08];29(2). Available from: http://revista.uninga.br/index.php/uningareviews/article/view/1948

24. Silva DSD, Tavares NVS, Alexandre ARG, Freitas DA, Brêda MZ, Albuquerque MCS, et al. Depression and risk of suicide in professional Nursing: integrative review. Rev Esc Enferm USP. 2015;49(6):1027-36. https://doi.org/10.1590/S0080-623420150000600020

25. Oliveira AV, Nascimento EB, Lima RN, Aoyama EA. Suicídio entre os profissionais de saúde. ReBIS-Rev Bras Interdisc Saúde [Internet]. 2020 [cited 2020 Jun 08];2(4):11-6. Available from: http://revista.rebis.com.br/index.php/rebis/article/view/389/149

26. Moraes SM, Magrini DF, Zanetti AC, Santos MA, Vedana KG. Atitudes relacionadas ao suicídio entre graduandos de enfermagem e fatores associados. Acta Paul Enferm. 2016;29(6):643-9. https://doi.org/10.1590/1982-0194201600090

27. Gonçalves AM, Sequeira C, Duarte JC, Freitas PP. Suicidal ideation on higher education students: influence of some socialdemographic, academic, and behavioural variables. Millennium [Internet]. 2014 [cited 2020 Jun 08];48(30):191-203. Available from: http://www.ipv.pt/ millenium/Millenium47/16.pdf

28. Einsenberg D, Gollust S, Golberstein E, Hefner J. Am J Orthopsychiatr. 2007;77(4):534-42. https://doi.org/10.1037/0002-9432.77.4.534

29. Durkheim E. O suicídio: estudo de sociologia. 2a ed. São Paulo (SP): Martins Fontes; 2011.

30. Weinberg I, Ronningstam E, Goldblatt MJ, Schechter M, Wheelis J, Maltsberger JT. Strategies in treatment of suicidality: identification of common and treatment-specific interventions in empirically supported treatment manuals. J Clin Psychiatry. 2010;71(6):699-706. https:// doi.org/10.4088/JCP.08m04840blu 